\title{
UPAYA MENINGKATKAN HASIL BELAJAR, AKTIVITAS DAN SIKAP PADA MATERI GETARAN, GELOMBANG DAN BUNYI, MELALUI METODE DISKUSI, OBSERVASI, DAN EKSPERIMEN
}

\author{
Yuni Lestari Purnomowati \\ SMK Negeri 3 Metro \\ Email: Yunilestari_Purnomowati@yahoo.co.id
}

\begin{abstract}
Abstrak
Penelitian dilakukan menggunakan metode Penelitian Tindaan Kelas (PTK). Penelitian ini dilaksanakan di SMKN 3 Metro pada siswa Kelas XI-TKJa semester genap Tahun Pelajaran 2012/2013 berjumlah 31 siswa. Sasaran perubahan dalam penelitian ini yaitu peningkatan hasil, aktivitas dan sikap siswa terhadap pelajaran Fisika. Peneliti dapat menyimpulkan bahwa peningkatan hasil belajar getaran, gelombang dan bunyi terjadi karena kerjasama siswa selama proses pembelajaran menumbuhkan suasana yang nyaman sekaligus kompetitif. Perubahan sikap siswa terhadap pelajaran Fisika semakin baik. Ketika pembelajaran fisika mampu memberikan apa yang diharapkan oleh siswa, yaitu siswa merasa nyaman, tidak terintimidasi oleh guru dan teman karena keterbatasan yang dimilikinya, terlibat dengan teman sejawat pada saat menyelesaikan tugas-tugas yang diberikan dengan diskusi, melakukan observasi, dan bereksperimen, maka persepsi terhadap fisika sebagai objek menjadi berubah lebih baik. Adanya interaksi siswa dengan media pembelajaran karena kegiatan mendiskusikan, mengobservasi, dan melakukan eksperimen mendorong siswa menjadi aktif selama proses pembelajaran.

Kata Kunci: Hasil Belajar, aktivitas, sikap, diskusi, observasi, eksperimen
\end{abstract}

\section{PENDAHULUAN}

Fisika masih tetap menjadi mata pelajaran yang dianggap berat. Hal tersebut ditandai dengan hasil belajar siswa pada mata pelajaran Fisika masih rendah. Hal ini wajar karena memang masih sangat banyak siswa Sekolah Menengah Kejuruan
(SMK) yang menganggap bahwa Fisika itu adalah pelajaran yang sulit. Sulit karena Fisika merupakan pelajaran hitungan dengan berbagai materi yang kompleks.

Persepsi siswa semakin buruk ketika para guru kurang dapat menghadirkan proses pembelajaran yang menarik. Menarik dalam arti 
Yuni Lestari - Upaya Meningkatkan Hasil ...

bahwa siswa mau terlibat secara aktif selama proses pembelajaran karena guru mengemas kegiatan pembelajaran tersebut dengan menggunakan berbagai media interaktif yang relevan, metode yang mengkondisikan siswa untuk berpartisipasi sehingga para siswa dapat merasakan bahwa mereka adalah subjek dalam belajar.

Berbagai kegiatan dalam kehidupan keseharian kita tidak pernah terlepas dari konsep Fisika. Bagaimana getaran mempengaruhi kecepatan, bagaimana cahaya dan gelombang merambat dan digunakan untuk sonar dalam kapal selam, dan banyak hal lainnya merupakan kejadian yang menarik dalam Fisika dengan getaran, gelombang dan bunyi. Pengetahuan tentang gerak getaran, gelombang dan bunyi sangat penting untuk dikuasai karena mendasari perkembangan teknologi dan industri. Oleh karenanya pengetahuan getaran, gelombang dan bunyi harus dikuasai oleh siswa SMK, termasuk siswa-siswa SMK Negeri 3 Metro. Bahkan pengetahuan tersebut diberikan sejak awal pada
Kelas XI sebagai pengetahuan prasyarat untuk kompetensi berikutnya.

Menggali dan memahami konsep dari kegiatan eksperimen atau simulasi, dan materi bisa dilakukan diskusi yang mendalam antarsiswa dalam kelas. Kemudian untuk memperkuat hasil diskusi siswa dapat diberi latihan soal dan pertanyaan sesuai dengan indikator SK Menerapkan getaran, gelombang dan bunyi. Gabungan model kooperatif dengan metode diskusi, observasi, dan eksperimen memberikan ruang yang lebih besar terhadap upaya peningkatan aktivitas siswa dalam pembelajaran dan hasil belajar Fisika. Tentunya pembelajaran akan berjalan dengan baik dan memberikan hasil yang maksimal ketika siswa terlibat secara aktif dalam proses pembelajaran.

Tujuan penelitian adalah sebagai berikut:

1) meningkatkan hasil belajar siswa Kelas XI-TKJa dalam pembelajaran Fisika pada SK Menerapkan getaran, gelombang dan bunyi di SMKN 3 Metro; 
Yuni Lestari - Upaya Meningkatkan Hasil ...

2) mendeskripsikan perubahan akhirnya, yaitu peningkatan hasil, sikap siswa Kelas XI-TKJa aktivitas dan sikap siswa terhadap SMKN 3 Metro terhadap Fisika; pelajaran Fisika. Sasaran perubahan

3) meningkatkan aktivitas siswa Kelas XI-TKJa dalam pembelajaran kooperatif pada mata pelajaran Fisika di SMKN 3 Metro. yang ditetapkan dalam PTK dapat dilihat pada Tabel 1.

Prosedur pelaksanaan penelitian tindakan kelas itu meliputi (1) planning, (2) acting, (3)

Tabel 1. Sasaran Perubahan

\begin{tabular}{|l|l|l|}
\hline \multicolumn{1}{|c|}{ Tujuan } & \multicolumn{1}{|c|}{ Sasaran Perubahan } & Vol \\
\hline 1. Hasil belajar Fisika & Siswa mendapatkan skor $>7,5$ & $75 \%$ \\
\hline 2. Sikap Terhadap Fisika & Siswa bersikap positif terhadap Fisika & $100 \%$ \\
\hline 3. Aktivitas belajar Fisika & $\begin{array}{l}\text { Siswa meningkatkan aktivitas sampai } \\
\text { pada kategori aktif }\end{array}$ & $75 \%$ \\
\hline
\end{tabular}

METODE

Penelitian

dilakukan

menggunakan metode Penelitian

Tindaan Kelas (PTK). Penelitian ini dilaksanakan di SMKN 3 Metro pada siswa Kelas XI-TKJa, berjumlah 31 orang siswa, Semester Genap, Tahun Pelajaran 2012/2013. Penelitian dilaksanakan selama dua bulan dari bulan Februari sampai dengan bulan April tahun 2013. PTK dilakukan sesuai dengan jadwal jam pembelajaran. Sasaran perubahan memudahkan peneliti melihat ketercapaian tujuan tiap siklus dalam menunjang pencapaian tujuan observing, (4) reflecting. Langkahnya disebut dengan siklus, dan pelaksanaannya tidak hanya cukup satu kali, jika ternyata satu siklus belum menunjukkan adanya perubahan, maka dilakukan secara berulang sampai benar-benar tampak adanya perubahan sebagaimana yang diharapkan, (Arikunto, et all. 2006:117).

Data dikumpulkan melalui tes tertulis hasil belajar, pengamatan aktivitas siswa selama pembelajaran, dan angket sikap siswa terhadap pelajaran Fisika. Tes hasil belajar diberikan pada akhir setiap siklus. 


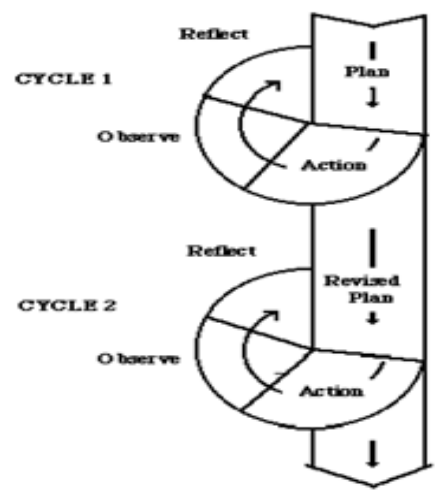

Gambar 1. Alur Pelaksanaan Penelitian Tindakan Kelas

Aktivitas siswa diamati selama pencarian pengetahuan secara aktif proses pembelajaran, dan angket oleh manusia, dan dengan sendirinya siswa juga diberikan setelah memberi hasil yang paling baik, pelaksanaan pembelajaran.

(Trianto, 2007:26). Dengan kata lain, kooperatif memfasilitasi proses

\section{HASIL DAN PEMBAHASAN} tumbuh kembangnya kecerdasan

Data hasil hasil belajar seluruh siklus ditampilkan pada gambar 2 . Sesuai dengan pendapat bahwa, interpersonal dan intrapersonal yang pada akhirnya membantu "Belajar penemuan sesuai dengan meningkatkan kecerdasan intelektual.

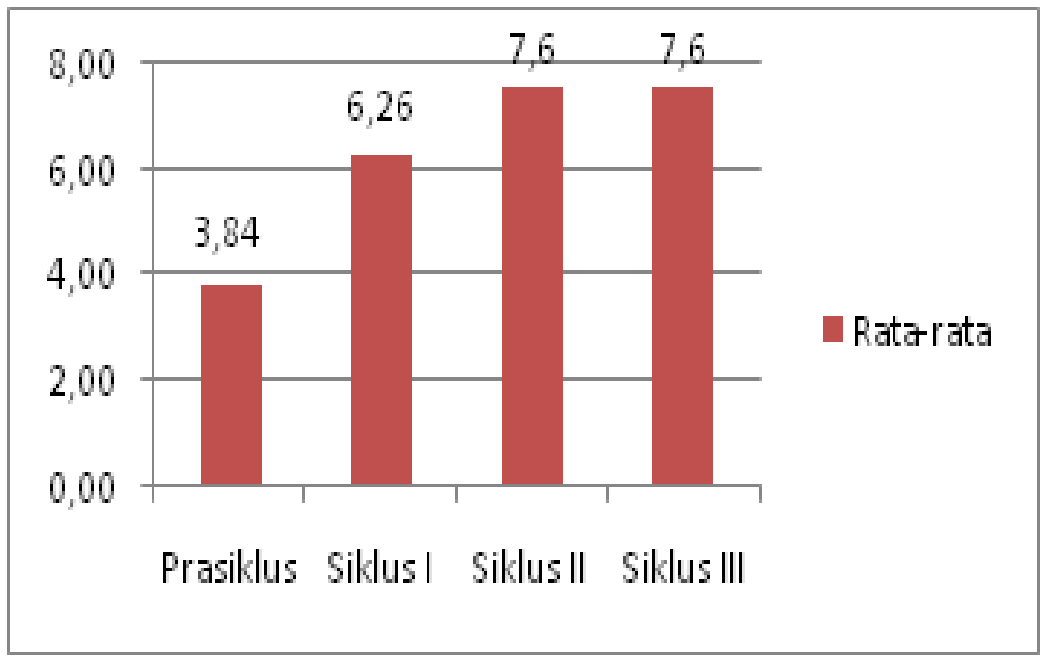

Gambar 2. Perolehan Rata-rata Hasil Belajar Seluruh Siklus 
Yuni Lestari - Upaya Meningkatkan Hasil ...

Interaksi antar siswa dapat menjadi media untuk menerapkan dan mengakomodasi sikap dan pendirian yang satu terhadap yang lain. Siswa belajar meningkatkan kemampuan interaksi dalam memimpin, berdiskusi, bernegosiasi dan mengklarifikasi berbagai masalah dalam menyelesaikan tugastugas. Dengan demikian siswa dapat mempelajari dan mempraktikkan berbagai sikap dan perilaku sosial dalam kelompok belajar. Adanya saling tukar informasi dan kerjasama membawa pada bertambahnya informasi yang disimpan oleh otak. Dengan semakin bertambahnya informasi yang disimpan tersebut, maka hasil belajar menjadi lebih tinggi. Hal tersebut didukung oleh pendapat "Proses pembelajaran perlu mendorong siswa untuk mengkomunikasikan gagasan hasil kreasi dan temuannya kepada siswa lain, guru atau pihak-pihak lain. Proses pembelajaran memungkinkan siswa bersosialisasi dengan menghargai perbedaan pendapat, sikap, kemampuan, dan hasil, (Yamin, Martinis. 2004:15).
Data hasil tes hasil belajar secara keseluruhan menunjukkan adanya peningkatan hasil belajar siswa pada KD Menguasai hukum getaran, gelombang dan bunyi. Terdapat peningkatan secara linier pada keseluruhan siklus. Peningkatan hasil belajar secara linier tersebut menunjukan bahwa metode kooperatif dengan difasilitasi diskusi, observasi dan eksperimen mampu mendorong pengembangan potensi siswa dalam belajar. Para siswa terdorong untuk berbuat aktif secara pembelajaran. Kondisi ini menunjukkan bahwa PBM yang diselenggarakan memberikan kesempatan kepada siswa berbuat semaksimal mungkin membangun pengetahuan menjadi miliknya sendiri.

Upaya untuk mengeluarkan pendapat menjadi sebuah jalan bagi keluarnya informasi yang disimpan. Disinilah, kecerdasan interpersonal membantu memperlihatkan seberapa cerdas siswa tersebut kepada orang lain. Kritik, sanggahan, dan argumentasi menjadi hal yang mengasyikan ketika dibangun dalam 
kerangka kooperatif yang penuh dengan toleransi. Tentu ada indikasi jengkel dan kecewa dalam proses diskusi, tetapi guru dengan perannya sebagai pengelola kelas menetralisir kecenderungan tersebut.

Pada saat yang sama, ketika siswa dapat menerima upaya guru untuk menetralisir kekecewaan terhadap proses dan hasil diskusi Menguasai hukum getaran, gelombang dan bunyi, siswa telah belajar bagaimana mengendalikan diri dan menerapkan pengetahuan dalam konteks diskusi kelompok, kelas, dan presentasi. Tantangan yang diberikan ketika mereka diberi tugas sebagai media untuk mendiskusikan melalui observasi dan eksperimentasi dengan memberikan deskripsi tugas yang jelas.

Pada siklus II rata-rata hasil belajar mencapai 7,6. Terakhir pada siklus III juga menunjukkan rata-rata hasil belajar 7,6. Tidak ada perubahan rata-rata Kelas XI-TKJa pada siklus II juga terdapat pada siklus III. Pencapaian hasil belajar telah melebihi sasaran perubahan.

Perkembangan sikap siswa terhadap Fisika ditampilkan pada gambar 3 .

Pada prasiklus, siswa berpredikat sangat negatif ada sebanyak $10 \%$, predikat negatif $52 \%$, predikat positif $29 \%$, dan predikat sangat positif $0 \%$.

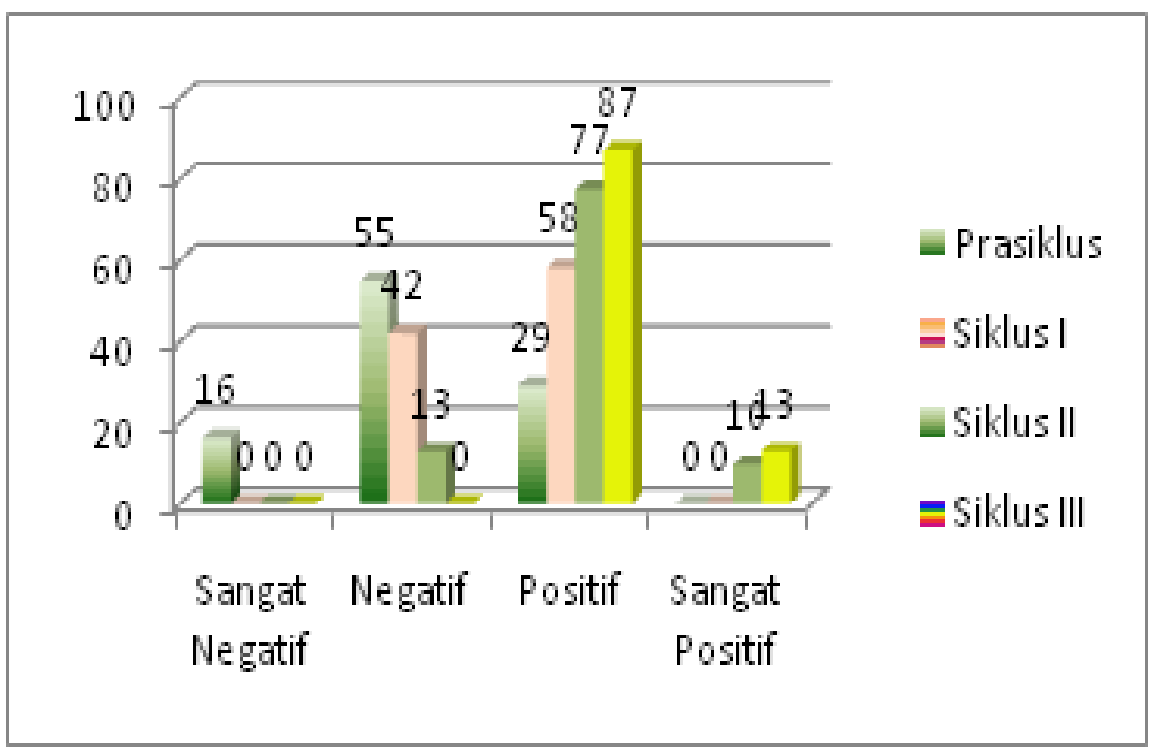

Gambar 3. Perubahan Sikap Terhadap Fisika Seluruh Siklus 
Pada siklus I predikat sangat negatif berubah menjadi 0\%, predikat negatif menjadi $42 \%$, predikat positif menjadi 58\%, dan belum ada predikat sangat positif. Pada siklus II tidak ada predikat sangat negatif, predikat negatif menjadi $11 \%$, predikat positif menjadi $77 \%$, dan predikat sangat positif menjadi $10 \%$.

Pada siklus III, tidak ada siswa berpredikat sangat negatif dan negatif. Predikat positif $81 \%$ dan sangat positif 19\%. Dengan demikian dapat dikatakan $100 \%$ siswa telah bersikap positif dan sangat positif terhadap Fisika pada siklus III.

Kurangnya siswa dalam menguasai pelajaran Fisika bukan materi dan juga tingkat kesulitan dari materi tersebut. Selain itu menjadi guru juga menjadi faktor yang mempengaruhi kesuksesan dalam memahami pelajaran Fisika. Guru berperan besar dalam menarik minat siswa untuk mempelajari pelajaran fisika. Pelajaran sesulit apapun jika guru yang mengajar sudah kita senangi dalam arti kita merasa mudah memahami pelajaran jika diterangkan guru tersebut, maka otomatis siswa akan semangat belajar Fisika. Salah satu upaya untuk disenangi siswa adalah dengan menggunakan model kooperatif yang diintegrasikan dengan diskusi, pengamatan, dan eksperimen

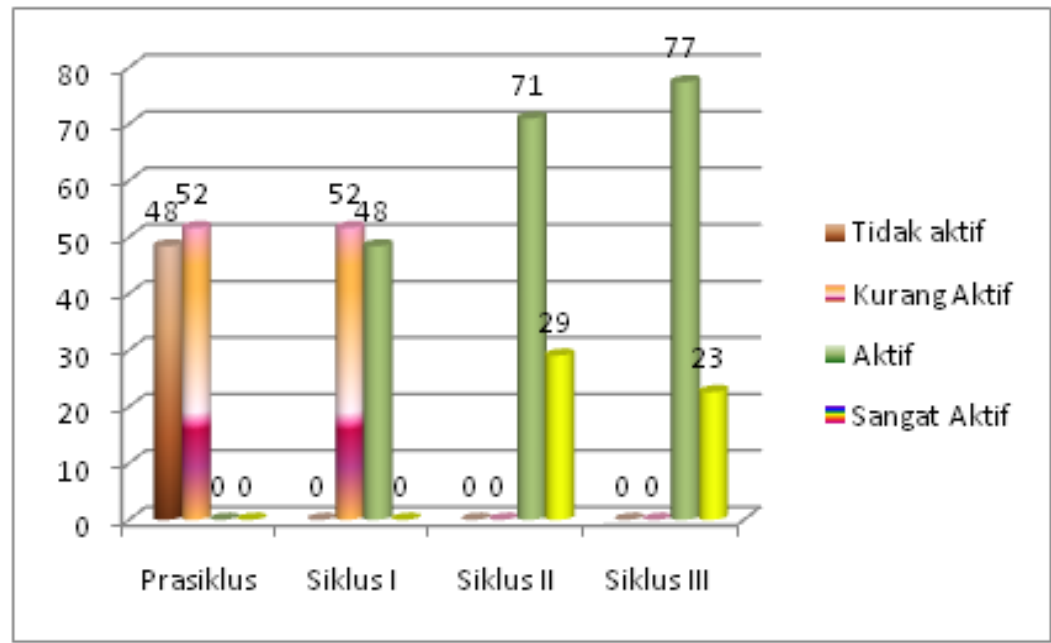

Gambar 4. Sebaran Aktivitas Siswa Terhadap Fisika Seluruh Siklus

disebabkan kemalasan siswa saja, tetapi juga bergantung pada jenis 
Data aktivitas siswa dalam pembelajaran Fisika, pada siklus III ditampilkan pada gambar 4. Pada Prasiklus, predikat tidak aktif sebanyak $48 \%$, predikat kurang aktif sebanyak 52\%, predikat aktif dan sangat aktif tidak ada.

Pada siklus I predikat tidak aktif menjadi $0 \%$, predikat kurang aktif $52 \%$, predikat aktif $48 \%$ dan sangat aktif 0\%. Pada siklus I tidak ada predikat tidak aktif dan kurang aktif, predikat aktif menjadi $67 \%$ dan predikat sangat aktif menjadi $29 \%$.

Pada siklus II, tidak ada siswa yang tidak dan kurang aktif. Predikat tidak dan kurang aktif. Predikat aktif ada $78 \%$ dan sangat aktif $22 \%$. sehingga $100 \%$ siswa telah menunjukan aktivitas selama proses pembelajaran. Sasaran perubahan aktivitas pada siklus III tidak terlalu berubah dari siklus II sehingga siklus dihentikan.

Peningkatan signifikan terjadi dari Prasiklus ke siklus I, tetapi tidak signifikan pada Prasiklus ke I, dan ke II-III. Peningkatan tersebut dapat dilihat pada gambar 5. Rata-rata hasil belajar pada Prasiklus ke siklus I meningkat 2,42 kemudian meningkat lebih rendah sebesar 1,32 di siklus II,

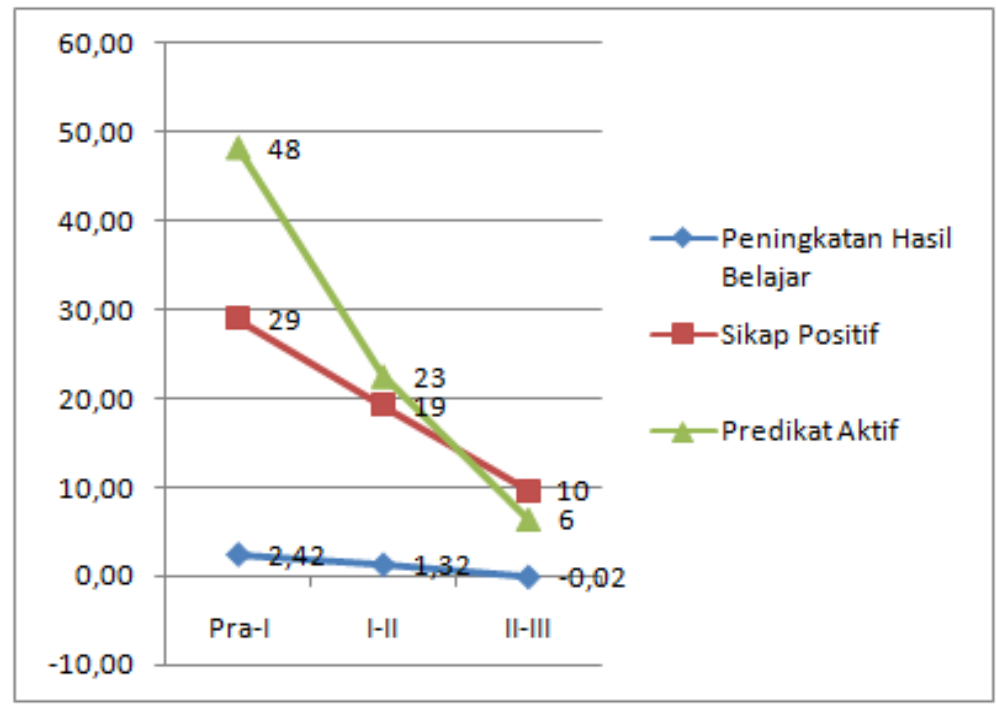

Gambar 5. Peningkatan Rata-rata Hasil Belajar, Sikap Positif, dan Predikat Aktif Seluruh Siklus

aktif ada $77 \%$ dan sangat aktif $25 \%$. Pada siklus III, tidak ada siswa yang dan turun 0,02 pada siklus III. Peningkatan sikap positif terhadap 
Fisika terjadi secara signifikan dari Prasiklus ke siklus I dan dari siklus I ke II tetapi tidak signifikan pada siklus II ke III. Peningkatan dari Prasiklus ke siklus I dan dari siklus I ke II merupakan perubahan sikap yang signifikan, yaitu sebesar 29\%, tetapi perubahan tersebut menjadi lebih kecil pada siklus III karena sudah mendekati $100 \%$ siswa bersikap positif. Peningkatan predikat keaktifan siswa selama proses pembelajaran secara sangat signifikan dari Prasiklus I ke siklus I, dan signifikan dari siklus I ke II tetapi tidak signifikan pada siklus II ke III. Peningkatan dari siklus I ke siklus I dan dari siklus I sebesar $48 \%$, kemudian dari siklus I ke II yaitu sebesar $23 \%$, tetapi perubahan tersebut menjadi lebih kecil pada siklus III karena mendekati $100 \%$.

Ketertarikan terhadap topik diskusi apalagi ada beberapa siswa yang cenderung bersikap negatif terhadap konsep Fisika memberi ruang aktivitas pembelajaran lebih dinamis. Tentulah dipahami bahwa, aktivitas siswa merupakan bagian yang mendasar yang dituntut dalam proses pembelajaran. Keaktifan siswa dalam proses pembelajaran akan menyebabkan interaksi yang tinggi antara guru dengan siswa ataupun antara siswa dengan siswa itu sendiri. Hal ini akan mengakibatkan suasana kelas menjadi segar dan kondusif, dimana masing-masing siswa dapat melibatkan kemampuannya semaksimal mungkin. Aktivitas yang timbul dari siswa akan mengakibatkan pula terbentuknya pengetahuan dan keterampilan yang akan mengarah pada peningkatan hasil.

Pada siklus I, tidak semua siswa memperlihatkan predikat aktif, hal ini karena masih ada persepsi negatif tentang pembelajaran kooperatif. Tidak semua siswa ingin menjadi lebih baik secara bersama, beberapa di antaranya ingin menunjukan bahwa mereka lebih baik dari yang lain. Selain itu, di samping banyak sisa mempunyai kesan negatif mengenai kegiatan kerja sama atau belajar dalam kelompok, banyak siswa juga tidak senang apabila bekerjasama dengan siswa yang lain. 
Yuni Lestari - Upaya Meningkatkan Hasil ...

Siswa yang tekun merasa harus bekerja melebihi siswa yang lain, sedangkan siswa yang kurang mampu merasa minder ditempatkan dalam satu grup dengan siswa yang lebih pandai. Keadaan inilah yang harus dinetralisir pada siklus I. Dan ketika persepsi negatif tersebut mampu dinetralisir oleh guru, maka kerjasama antarteman dalam kelompok berlangsung dengan baik pada siklus II dan siklus III.

Sebagai satu faktor penting dalam kegiatan belajar mengajar, aktivitas belajar mengingatkan bahwa kegiatan belajar mengajar diadakan dalam rangka memberi-kan pengalaman-pengalaman belajar pada siswa. Jika siswa aktif dalam kegiatan tersebut kemungkinan besar akan dapat mengambil pengalamanpengalaman belajar tersebut. Hal ini mendukung apa yang telah disampaikan bahwa, "Melalui pengalaman inilah diharapkan terjadinya pengembangan berbagai aspek yang terdapat dalam individu, seperti aspek minat, bakat, kemampuan, potensi, dan sebagainya" (Sanjaya,2007:29). Kegiatan belajar dipandang sebagai kegiatan komunikasi antara siswa dan guru. Kegiatan komunikasi ini tidak akan tercapai apabila siswa tidak dapat aktif dalam kegiatan belajar mengajar. Dengan adanya keaktifan siswa dalam proses belajar mengajar kemungkinan besar hasil belajar yang dicapai akan memuaskan. Metode diskusi, observasi, dan melakukan eksperimen memberikan keinginan untuk menjawab substansi dibalik fenomena penyajian membuat siswa berpikir, bertanya, dan mendiskusikannya dengan teman. Hal ini membangkitkan mereka untuk turut aktif dalam pembelajaran. Bersamaan dengan adanya peningkatan hasil belajar pada setiap siklus, aktivitas belajar siswa juga mengalami peningkatan. Prinsip-prinsip belajar yang berkaitan dengan perhatian, keaktifan, keterlibatan langsung atau pengalaman, pengulangan, tantangan balikan, dan penguatan serta perbedaan individual, ternyata memang memberikan kebermaknaan proses belajar dalam diri setiap siswa. Hal sejalan dengan pendapat 
bahwa, "Aktivitas merupakan segala bentuk kegiatan yang dilakukan oleh siswa yang bersifat pikiran atau jasmani maupun mental atau rohani dimana keduanya sangat terkait dalam mencapai hasil belajar baik aktivitas fisik ataupun mental", (Silberman, Mell. 1996: 85). Apa yang membuat seseorang menjadi aktif adalah karena orang tersebut mempunyai ketertarikan dengan topik. Topik Fisika menjadi topik yang menarik karena melibatkan pemahaman fenomena nyata kehidupan sekitar siswa. Aktivitas tersebut merupakan rangsangan secara emosi dan kejiwaan dan mempengaruhi kinerja otak secara internal da mengarahkan perilaku.

\section{PENUTUP}

\section{Kesimpulan}

Peneliti dapat menyimpulkan bahwa:

1) Peningkatan hasil belajar getaran, gelombang dan bunyi terjadi karena kerjasama siswa selama proses pembelajaran menumbuhkan suasana yang nyaman, kooperatif sekaligus kompetitif. Nyaman karena siswa yang kurang paham dapat menanyakannya dengan teman dalam kelompok tanpa rasa gengsi atau minder. Kompetitif karena setiap kelompok berusaha untuk lebih baik dari kelompok lain.

2) Perubahan sikap siswa terhadap pelajaran Fisika semakin baik. Ketika pembelajaran fisika mampu memberikan apa yang diharapkan oleh siswa, yaitu siswa merasa nyaman, tidak terintimidasi oleh guru dan teman karena keterbatasan yang dimilikinya, terlibat dengan teman sejawat pada saat menyelesaikan tugas-tugas yang diberikan dengan diskusi, melakukan observasi, dan bereksperimen, maka persepsi terhadap fisika sebagai objek menjadi berubah lebih baik.

3) Adanya interaksi siswa dengan media pembelajaran karena kegiatan mendiskusikan, mengobservasi, dan melakukan eksperimen mendorong siswa menjadi aktif selama proses pembelajaran. 
Yuni Lestari - Upaya Meningkatkan Hasil ...

\section{Saran}

Berdasarkan hasil PTK dapat disarankan antara lain :

1) Guru harus menerangkan sejelasjelasnya tentang hasil yang ingin dicapai sehingga ia mengetahui pertanyaan-pertanyaan yang perlu dijawab dengan eksperimen.

2) Guru perlu membicarakan bersama-sama dengan siswa tentang langkah yang dianggap baik untuk memecahkan masalah dalam eksperimen, serta bahanbahan yang diperlukan, variabel yang perlu dikontrol dan hal-hal yang perlu dicatat.

\section{DAFTAR PUSTAKA}

Arikunto, Suharsimi. Suhardjono dan Supardi. 2006. Penelitian Tindakan Kelas. Jakarta: Bumi Aksara.

Sanjaya, Wina 2007. Strategi Pembelajaran, Berorientasi Standar Proses Pendidikan. Jakarta: Kencana Prenada Media Group.

Silberman, Mell. 1996. Active Learning. Diterjemahkan Allyn dan Bescon. Jakarta: Gramedia

Trianto, 2007. Model-model pembelajaran Inovatif Berorientasi Konstruktivistik. Surabaya: Prestasi Pustaka.
Yamin, Martinis. 2004. Strategi Pembelajaran Berbasis Kompetensi. Jakarta: Gaung Persada Press. 
p-ISSN: 2337-5973

e-ISSN: 2442-4838

JPF Jurnal Pendidikan Fisika

Universitas Muhammadiyah Metro 